\title{
Малигнен меланом на десен максиларен синус и орбита осем години след отстраняване на първичен увеален меланом вляво, комбиниран с хепатоцелуларен карцином
}

\author{
Д. Марковскиㄱ, К. Джамбазовㄹ, Д. Вичева ${ }^{1}$, \\ Д. Пазарджиклиев ${ }^{1}$, Хр. Желязков ${ }^{2}$ \\ ${ }^{\prime}$ Катедра по оториноларингология, Медицински университет - Пловдив \\ ${ }^{2}$ Катедра по неврохирургия, Медицински университет - Пловдив
}

\section{Резюме:}

Злокачествените тумори на околоносните кухини са сравнително редки и представляват около $3 \%$ от всички синоназални неоплазми. Малигненият меланом е висока смъртоносна меланоцитна неоплазма. Произходът му от максиларния синус е изключително рядък. Израства от малигнена трансформация на меланоцитите, които се намират в мукозата в цялото тяло.

Меланомите на околоносните кухини най-често са представени като регионални метастази, но е възможно да израснат отново в корелация с мултицентрична характеристика на увеален меланом.

\section{Въведение}

Меланомът може да се разпространи в близост до първичното огнище чрез разпространение (по лимфните съдове) и/или по хематогенен път до отдалечени места. Сателитни лезии може да се локализират в кожата или по съседство. Те понякога се наричат транзит метастази, което означава израстване в кожата на меланом на път да се разпространи към локалните лимфни възли. Всеки орган може да бъде засегнат с метастази от злокачествен меланом, но белите дробове и черният дроб са най-често атакуваните органи (2), с чернодробно предпочитание повече от всички други локализации (4). Някои автори смятат, че меланомите в околоносните кухини най-вероятно се развиват като регионални метастази, въпреки че е възможно да възникнат първично или като корелация и съответствие с мултицентрична характеристика на меланом (3). Орбиталното засягане е обикновено в най-напредналите случаи: T3-4 стадий на тумора. Стандартното лечение на избор е радикална ексцизия.

\section{Цел}

Запознаване с рядък клиничен случай на контралатерална метастаза от увеален малигнен меланом на максиларен синус и орбита осем и половина години след отстраняване на първичния тумор.

\section{Клиника}

Клинично повечето пациенти проявяват първоначално неспецифични симптоми с едностранна назална 
обструкция или кръвотечение от носа, като такива пациенти, често не успяват да търсят навременна лекарска помощ. Диагнозата може да бъде потвърдена от имунохимичен профил на оцветяване с анти-S100 и НMB-45 антитела, дори и в случай на пигмент меланин-меланом. Прогнозата е лоша, със средно време на преживяемост от 3.5 години.

\section{Клиничен случай}

В катедрата по оториноларингология към Медицински университет - Пловдив се хоспитализира рядък клиничен случай с клинико-патологична корелация на параназалните кухини (максиларен синус) и орбитални метастази от контралатерален увеален меланом, където първичният тумор е отстранен напълно с хирургична резекция (енуклеация на лявото око) през януари 1999 г., последвана от 5 курса на химиотерапия и имунотерапия.

Към март 2007 г. при контролни изследвания с коремна ехография са открити лезии на черния дроб с дължина 3,5 см. Резултатите показаха хепатоцелуларен карцином, който е лекуван с радиофреквентна аблация.

През юни 2007 г. пациентът за първи път почувствал болка в дясната буза, цветьт на кожата станал „син“" за няколко дни и паралелно с това забелязал екзофталм на дясното око в съчетание с периодично главоболие (Фиг. 1). При извършване

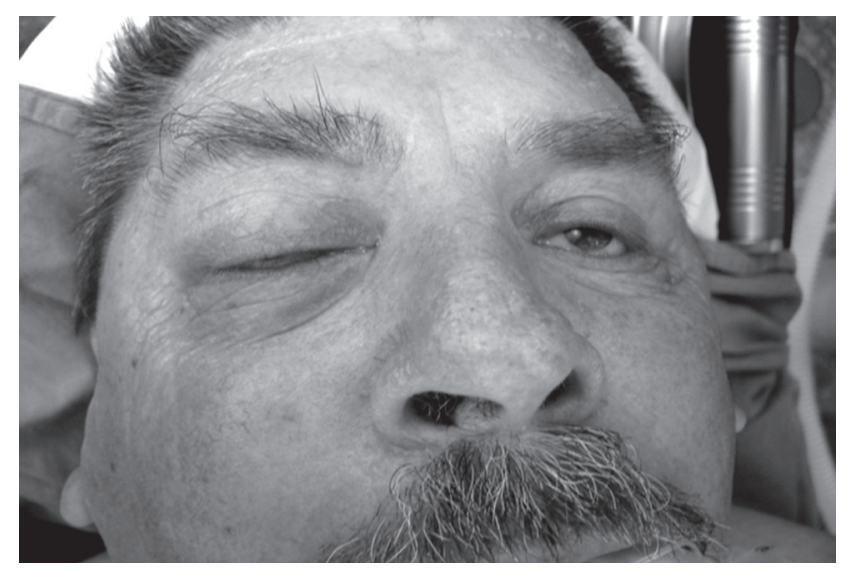

Фиг. 1. Клиничен случай на контралатерална метастаза от увеален малигнен меланом на максиларен синус и орбита осем и половина години след отстраняване на първичния тумор на меланом в лявото око

на биопсия се постави диагноза малигнен меланом на десния максиларен синус, 8 и половина години след първична локализация на меланом в лявото око. Хистопатологичният резултат и при двата меланома е един и същ вид, епителоидно клетьчен малигнен меланом.

При така направената компютър-томография на околоноснине кухини се показа солидна туморна маса в десния максиларен синус със засягане на околните структури, унищожаване на задната стена на максиларен синус и нахлуване в заднодолната стена на дясната орбита, без инволвиране на fissura supraorbitalis и $\mathrm{n}$. infraorbitalis dextra. Отчасти е засегнато и ретроорбиталното клетъчно пространството, задните етмоидални клетки, без патологични промени в главния мозък (Фиг. 2 и Фиг. 3).

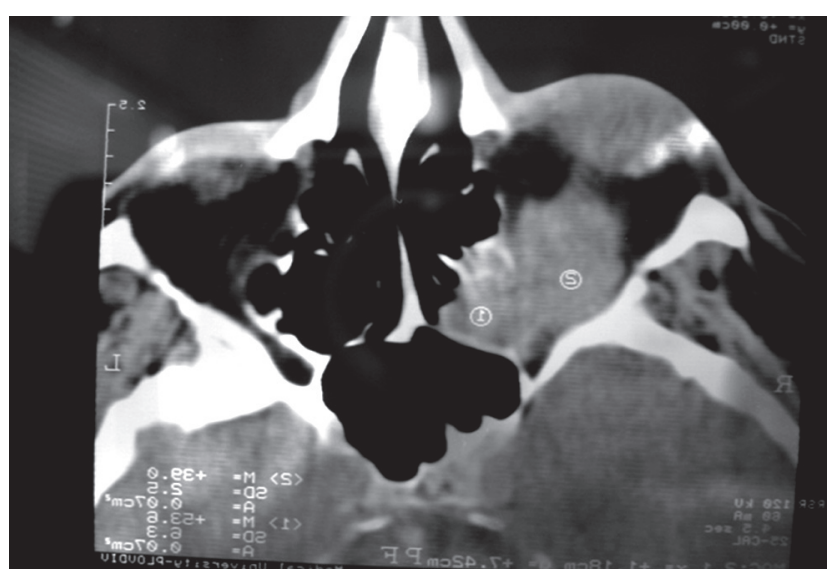

Фиг. 2.

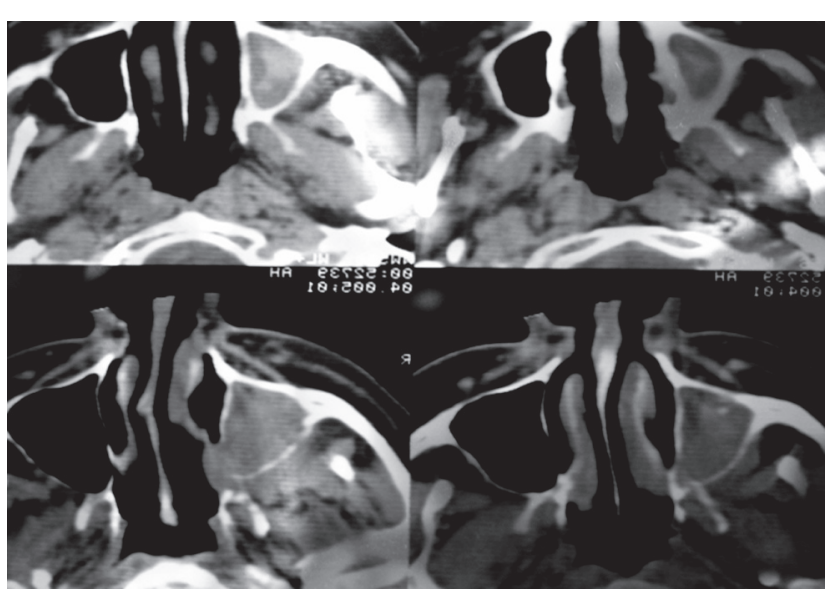

Фиг. 3.

\section{Клиничен резултат}

Наличният тумор бе радикално отстранен чрез медиофациална резекция тип Дифенбах-ВеберФъргюсън в комбинация с Калдвел-Люк, след което на пациента се препоръча да се обърне към онкологичен център за евентуална полихимиотерапия (Фиг. 4). 


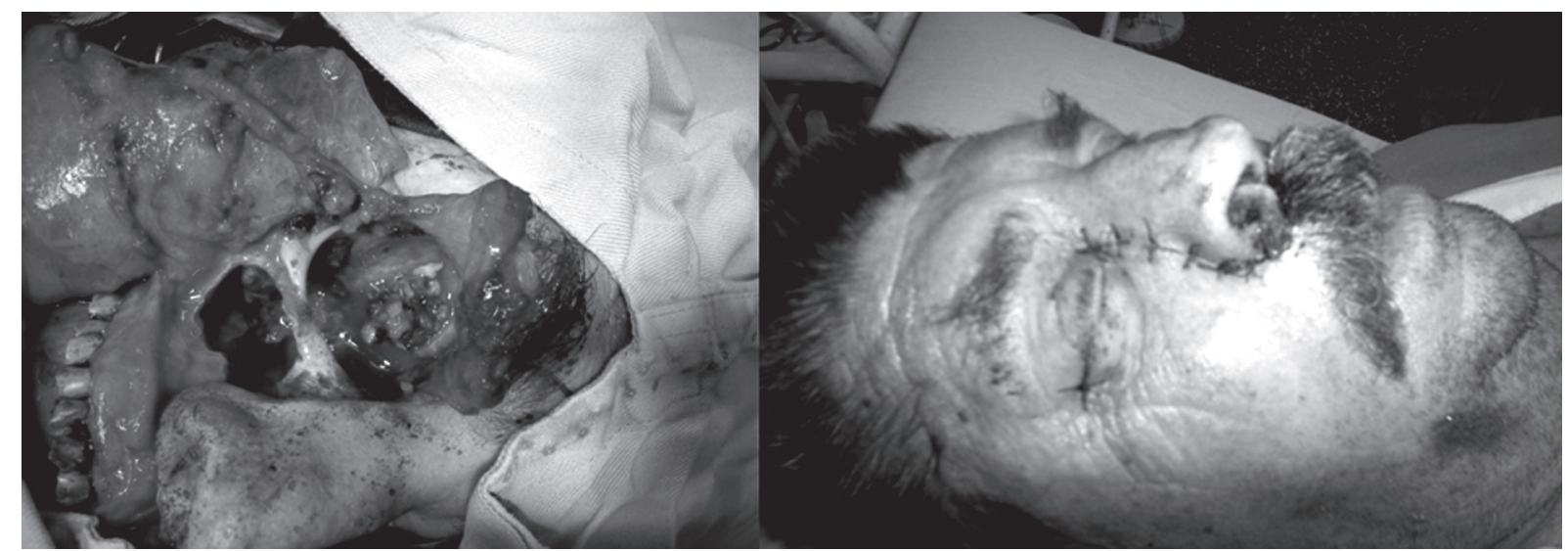

Фиг. 4. Пациентът по време на операцията

\section{Заключение}

Според литературната справка, която е направена от нашия колектив, ние смятаме, че това е уникален случай в рамките на подобна комбинация от симптоми и разпространение. Що се отнася до стадия на тумора и лошата прогноза, поради високия процент на генерализирани метастази, радикалната хирургична резекция може само да удължи оцеляване в отделни случаи на напреднал стадий на синуназалните неоплазми. Орбиталната декомпресия трябва да се разглежда като подобрение на качеството на живот на пациента в такива случаи.

\section{Лumepamypa:}

1. Choi, Yoon-Seok; Han Gil, Choi, Jeong-Seok; Zhang, Tae1. Two cases of malignant melanoma in the tribunate and the maxillary sinus. European archives of oto-rhino-laryngology, Volume 263, Issue 11 , November 2006, pp. 996-1000 (5)

2. www.CancerConsultats.com

3. Robertson DM, Hungerford JL, McCartney A. Malignant melanoma of the conjunctiva, nasal cavity, paranasal sinuses. Am J Ophthalmol 1989; 108: 440-2

4. Eskelin Sebastian. The development and early diagnosis of primary uveal melanoma and widespread.International Ophthalmologic Clinics, 2006: 46 (1)

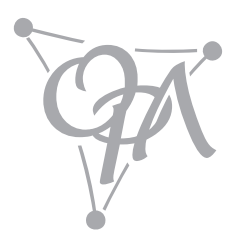

